\title{
DESIGNING URBAN PAVEMENT SUB-BASES TO SUPPORT TREES
}

\author{
by Palle Kristoffersen
}

\begin{abstract}
In Denmark, poor growth conditions for urban trees have been perceived as a problem since the 1980 s. Restricted planting-pit sizes are mainly responsible for this problem. In 1996, a survey found that the average size of municipal planting pits had increased from $0.1 \mathrm{~m}^{3}\left(3.5 \mathrm{ft}^{3}\right)$ in the late $1960 \mathrm{~s}$, to $3.4 \mathrm{~m}^{3}\left(120 \mathrm{ft}^{3}\right)$ in 1996 . To increase the volume of the planting pit, several materials have been introduced to mix with soil to allow root growth under pavements. Three methods are available for installing these materials under pavements. During the last 5 years, more than 800 trees have been planted on more than 30 sites using these materials and installation methods. Every method has advantages and disadvantages. No serious difficulties due to load-bearing capacity or frost heaves have been recorded.
\end{abstract}

Planting pits for urban trees are surrounded with soil that has been either unintentionally compacted or replaced with compacted road-building materials (Kopinga 1985; Lichter and Lindsey 1994; Randrup 1997). The restricted planting pits allow only limited root growth, and insufficient rooting volumes in urban situations often result in destructive roots. Roots outgrow the planting pits and often spread immediately below the pavement surface, lifting and eventually destroying the pavement. This is a serious and expensive problem that stresses trees (Kopinga 1991, 1992). Sycamore maples (Acer pseudoplatanus) grown under stressed conditions exhibit limited height growth, more capital axes, fewer cardinal axes, and twisted and crooked stems (Bonsen 1996). This irregularity of growth causes aesthetic as well as maintenance problems in system plantings in which all trees are important in forming a unified appearance. If system plantings are established in paved, partly paved, and unpaved areas, the chances of obtaining a homogeneous appearance will be reduced further.

The usual method of establishing urban trees in Denmark has been to plant trees in individual planting pits. The size of the planting pit has increased since the 1960 s, when it was often less than $0.1 \mathrm{~m}^{3}\left(3.5 \mathrm{ft}^{3}\right)$. Since then, the average volume of planting pits, as found in 11 Danish municipalities, has increased to $3.4 \mathrm{~m}^{3}\left(120 \mathrm{ft}^{3}\right)$, ranging from 0.8 to $8.1 \mathrm{~m}^{3}$ ( 28 to $286 \mathrm{ft}^{3}$ ) (Teilmann and Kristoffersen 1996).

Applying one of the predeveloped models to estimate soil volumes for urban trees based on the soil's water-holding capacity shows that a tree with a canopy diameter of $10 \mathrm{~m}(33 \mathrm{ft})$ requires a 35 to $40 \mathrm{~m}^{2}$ ( 377 to $431 \mathrm{ft}^{2}$ ) planting pit (Lindsey and Bassuk 1992). In urban areas, it is almost impossible to plan unpaved planting beds of this size. Therefore, several methods for integrating the growing media under paved surfaces have been described. These methods consist of a mix of medium-course sand (Couenberg 1994), a load-bearing matrix mixed of stones and soil (Grabosky and Bassuk 1995), and pavements constructed with a span above a growing media, such as top soil (Urban 1989).

In Denmark, pavements are defined to consist of a sub-base and a base, both usually compacted to densities that impede root growth, and of a top layer of bricks, pavers, or asphalt (Patterson 1977; Vejdirektoratet 1984). The subbase material usually consists of sand or other materials that promote drainage. The base is often made of screened and graded gravel but almost never concrete, as it is in the United States.

\section{Design and Installation Methods}

In Denmark, more than 800 trees were integrated into pavements at 30 different sites using a load-bearing matrix or different sand mixes. A number of matrix materials were used, and $3 \mathrm{mix}-$ ing methods have been developed.

Materials. Stones, ranging from 32 to 150 $\mathrm{mm}$ (1 to 6 in.) diameter gravel, granite, lava slags, crushed bricks, and blocks of Leca-concrete have been used as load-bearing matrixes (Table 1). Leca-concrete is made of 
Table 1. Materials and mixing methods used as sub-base to support trees.

\begin{tabular}{|c|c|c|c|c|c|c|}
\hline & \multicolumn{6}{|c|}{ Materials } \\
\hline & $\begin{array}{l}\text { Stones } \\
(80-150 \mathrm{~mm})\end{array}$ & $\begin{array}{l}\text { Stones/ } \\
\text { crushed stones } \\
(32-80 \mathrm{~mm}) \\
(32-45 \mathrm{~mm})\end{array}$ & $\begin{array}{l}\text { Leca-concrete } \\
\text { blocks } \\
(100 \times 100 \mathrm{~mm})\end{array}$ & $\begin{array}{l}\text { Crushed } \\
\text { lava } \\
(32-45 \mathrm{~mm})\end{array}$ & $\begin{array}{l}\text { Crushed } \\
\text { bricks } \\
(25-50 \mathrm{~mm}) \\
\end{array}$ & $\begin{array}{l}\text { Sand mix } \\
(0.2-0.5 \mathrm{~mm})\end{array}$ \\
\hline Installation methods & $\begin{array}{l}\text { water mix } \\
\text { dry mix }\end{array}$ & $\begin{array}{l}\text { premix } \\
\text { water mix }\end{array}$ & premix & $\begin{array}{l}\text { premix } \\
\text { water mix } \\
\text { dry mix }\end{array}$ & $\begin{array}{l}\text { premix } \\
\text { water mix }\end{array}$ & premix \\
\hline Growing medium & topsoil & topsoil & topsoil & topsoil & topsoil & $\begin{array}{l}\text { humus/ } \\
\text { compost }\end{array}$ \\
\hline $\begin{array}{l}\text { Density of material } \\
\left(\mathrm{g} / \mathrm{cm}^{3}\right)\end{array}$ & 2.7 & 2.7 & 1.0 & 1.8 & 1.8 & 2.6 \\
\hline $\begin{array}{l}\text { Porosity of material } \\
\text { (vol. }-\%)\end{array}$ & 0 & 0 & approx. 15 & approx. 55 & approx. 30 & 0 \\
\hline $\begin{array}{l}\text { Voids in compacted } \\
\text { material (vol. - \%) }\end{array}$ & 45 & $45 / 40$ & 56 & 38 & 35 & 45 \\
\hline
\end{tabular}

Leca nuts mixed with cement and formed to blocks. Leca is a commercial name and an acronym for Light Expanded Clay Aggregates. The Leca nuts consist of an inner clinkerized cellular structure with a hard, resistant outside coating. The material porosity is presumed to influence the air and water exchange in the soil mix.

Methods of installation. Soil is used to fill the voids in the load-bearing matrix. Because compacted soil impedes root growth, it is necessary to prevent compaction during the installation process. Three mixing and installation methods have been developed and tested: premixing before installation, water mixing during installation, and dry mixing during installation.

Premixing before installation. Stones and soil are mixed at a predetermined ratio. Mixing can be done with a front loader, a power shovel, a concrete mixer, or similar equipment. Separation of soil from stones may occur after mixing if the mixture is moved or transported; therefore, remixing before installation may be necessary to restore uniformity. The matrix of stone and soil is compacted after spreading to establish contact between the individual stones, thereby transferring the load of pedestrian and vehicles to the subgrade. When the soil and stone mix is compacted, the stones will be rearranged as the soil fills the voids (Harris 1971). To obtain the proper degree of compaction, the stone-soil mix should be installed in layers of no more than 15 to $20 \mathrm{~cm}$ (6 to 8 in.).

The correct mixture of stones and soil (i.e., the point at which the soil is not compacted during the installation) can be determined by measuring the stone weight per cubic unit or by filling a known volume of stones with water and then estimating the volume of the voids. The volume of soil added should be less than this volume. If the applied stone material has $20 \%$ voids after compacting, the correct mixing ratio of stone to soil will be 5:1. An incorrect mixing ratio of $4: 1$ will lead to a filling level of $125 \%$, which means that the soil will be compacted in the voids and the stones will not be touching each other. At a mixing ratio of $6: 1$, only $80 \%$ of the voids would be filled but, considering root growth, this seems to be sufficient and better than overfilling the voids and compacting the soil (Kristoffersen 1998).

Water mixing during installation. Layers of stones are installed and compacted. Then a layer of screened soil (e.g., sandy loam) is spread on top of the stones and watered into the voids. The stone layer can be up to $25 \mathrm{~cm}$ (10 in.) thick when stones of 80 to $150 \mathrm{~mm}$ ( 3 to 6 in.) in diameter are used. When using smaller stones and broken stones, the recommended thickness is 10 to $15 \mathrm{~cm}$ (4 to 6 in.).

Dry mixing during installation. Another method of mixing during installation is installing stones in layers of 15 to $25 \mathrm{~cm}$ (6 to $10 \mathrm{in}$.) and 


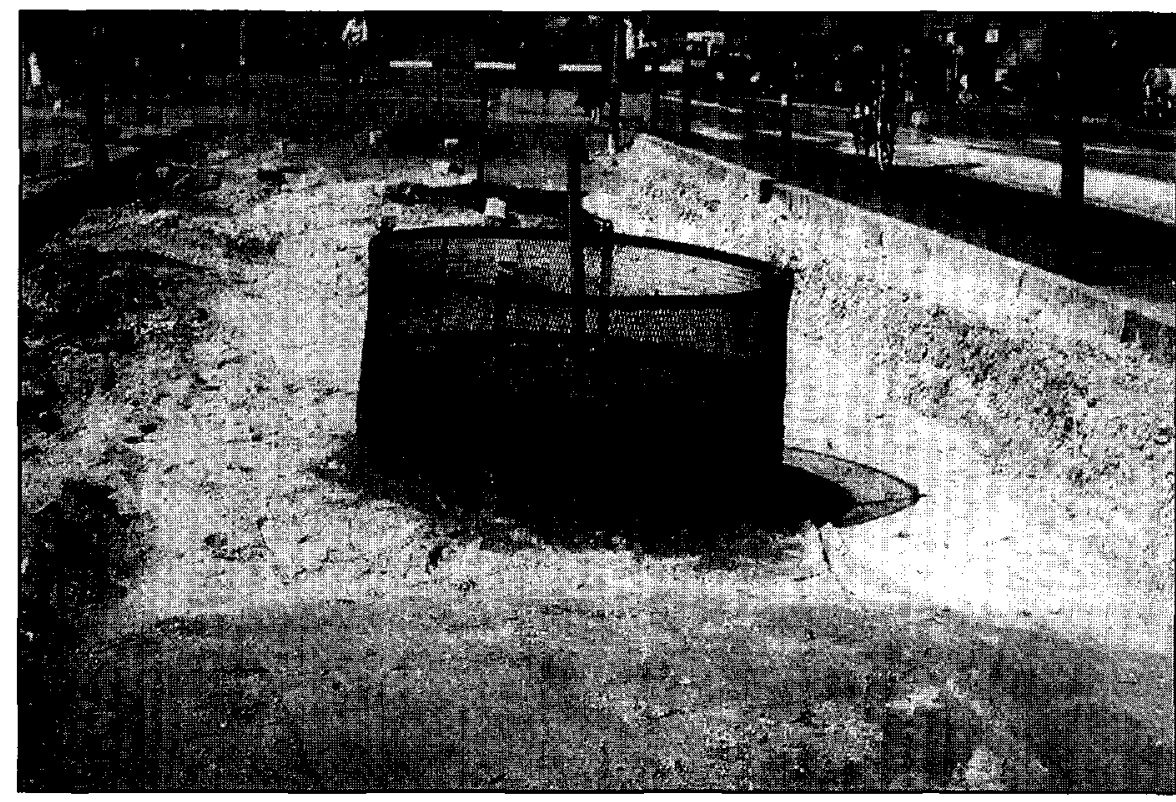

Figure 1. Use of sand mix at The Christians Havns Square, Copenhagen. The material is used in a $3-\mathrm{m}$ wide, $57-\mathrm{m}$ long pit, in which 7 linden trees (Tilia tomentosa) were planted. The soil in the planting pits is separated from the sand mix by a wire basket during the installation process.

\section{Technical Construction of Planting Site}

When topsoil and other materials containing humus are installed under pavements, there is a risk that the obstruction of aeration could cause anaerobic conditions. This risk is increased by insufficiencies in drainage (e.g., if the soil is compacted) (Harris 1992). Sufficient air movement in the soil or sand mix is achieved by installing a layer of stones or broken stones between the root growth area and the pavement above. The aeration layer receives air via subsequently filling the voids with dry soil by sweeping and vibration. Both the stones and the soil must be completely dry, and installation must be carried out in dry weather. The dry-mixing method has been used only with stones of 80 to $150 \mathrm{~mm}$ ( 3 to 6 in.) in diameter and is not suitable for use with smaller stones. This method can cause difficulties because most construction work is carried out when rainy weather can occur.

Sand mix. The Dutch experience has shown that uniform graded sand can be used to expand the rooting volume beneath pavements. The sand is mixed with up to $4 \%$ or $5 \%$ of humus in the form of compost or sphagnum. In Denmark, the sand mix has been used and installed as described by Couenberg (1994) (Figure 1). The intention of using sand $\mathrm{mix}$ is to achieve a compaction level of $70 \%$ to $80 \%$ proctor density (Couenberg 1994). Therefore, penetration resistance is measured to ensure that the degree of compaction does not exceed the critical limit for root growth. This quality check is not practiced in Denmark. pipes or the planting pit (Urban 1989) and should be covered with a suitable geotextile to prevent filling from the layers above (Figure 2). The same type of aeration layer is recommended when raising the grade around existing trees (Harris 1992). Although the effect of an aeration layer has not been documented in the Danish examples, it is considered to have a beneficial effect on the soil and the root growth (Smith 1995). The aeration layer may also be used to irrigate the trees (Urban 1989).

\section{Applications in Denmark}

More than 800 trees have been successfully planted since 1991 on more than 30 construction sites in Denmark using these alternative materials and methods.

Table 2 shows that stones or broken stones, in various size classes, are the most commonly used materials for load-bearing matrixes and are used with more than $75 \%$ of planted trees. Premixing before installation is the most frequently used installation method. Dry mixing dur- 


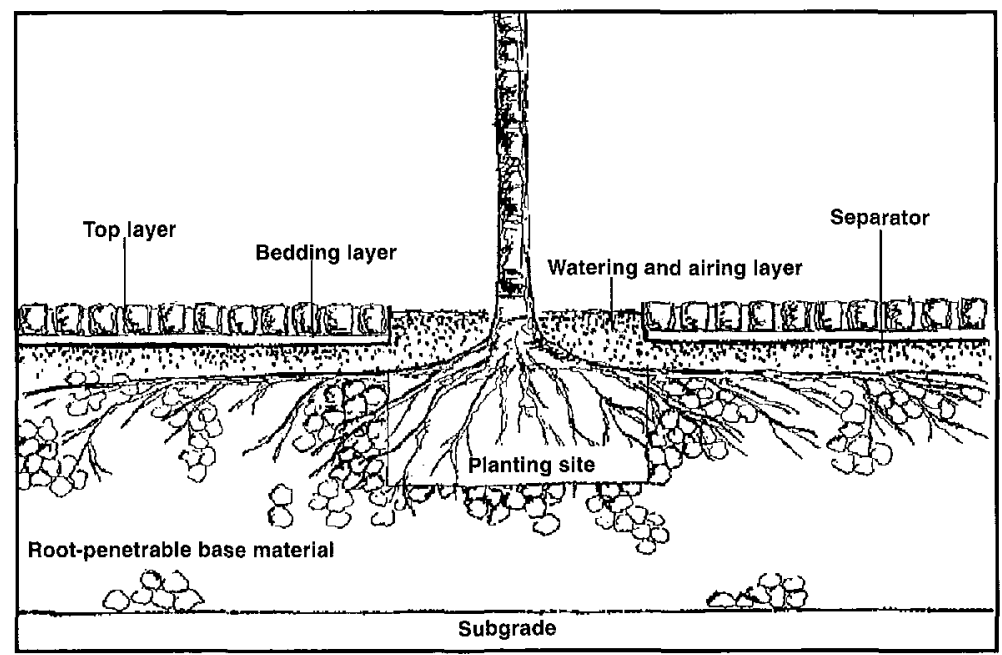

Figure 2. Pavement construction with load-bearing matrix and aeration layer.

ing installation is only occasionally used. Each installation method has advantages and disadvantages (Table 3).

The major disadvantages of using the premix of stone and soil is that separation might occur during transportation and installation. A tackifier can help the soil adhere to the stones (Grabosky and Bassuk 1995). The calculation of mixing ratio is also problematic. In a stone and soil mix, a calculated void percentage (e.g., 25\%) has often led to a recommended mixing ratio of $3: 1$. In one case, this ratio led to compaction of the soil in the voids, which caused subsequent ettling. The correct mixing ratio should have been $4: 1$ to secure $25 \%$ voids in a stone and soil mix. Dry mixing has been the most effective and practical method. However, the dry mixing method requires dry weather, dry stones, and dry soil.
Measurements of soil densities are included in the original Dutch method, in which sand mix was used (Couenberg 1994). Although the degree of compaction is intended to be optimized for plant growth, there is a risk of subsequent soil compaction of soil and settling of the pavement.

\section{Conclusion}

During the last 5 years, soil mixes, sand mixes, and load-bearing stone have been introduced for use in Denmark. Most landscape projects involving trees in paved areas use these new methods. No difficulties with load-bearing capacities, irregularities, or frost-heaving of pavements have been recorded. Compared to normal Danish conditions, the winter of 1995-1996 was long and cold, with continuous frost from the start of November to the middle of March. A top layer of at least $0.5 \mathrm{~m}$ (20 in.) was frozen, which influenced all layers of load-bearing mixes installed below pavements. None of the methods applied appear to have higher susceptibility to frost heave than does traditional pavement construction.

To reduce the visual effects of possible irregularities caused by heaves and settlements, landscape architects often changed the pavement on the load-bearing matrix materials so that it differed from the rest of the pavement. As a result, the possible height differences are less conspicuous than would be the case with uniform pavements. In addition, the change in pavement shows where the tree has its roots.

Table 2. Examples of load-bearing matrixes used in Denmark.

\begin{tabular}{|c|c|c|c|c|c|c|}
\hline & Stones & Lava & Bricks & Leca & Sand & Totals \\
\hline Premixing & $\begin{array}{l}8 \text { locations } \\
256 \text { trees }\end{array}$ & $\begin{array}{l}2 \text { locations } \\
3 \text { trees }\end{array}$ & $\begin{array}{l}6 \text { locations } \\
46 \text { trees }\end{array}$ & $\begin{array}{l}1 \text { location } \\
40 \text { trees }\end{array}$ & $\begin{array}{l}8 \text { locations } \\
114 \text { trees }\end{array}$ & $\begin{array}{l}25 \text { locations } \\
459 \text { trees }\end{array}$ \\
\hline $\begin{array}{l}\text { Water mixing during } \\
\text { installation }\end{array}$ & $\begin{array}{l}5 \text { locations } \\
181 \text { trees }\end{array}$ & $\begin{array}{l}2 \text { locations } \\
12 \text { trees }\end{array}$ & $\begin{array}{l}1 \text { location } \\
3 \text { trees }\end{array}$ & - & - & $\begin{array}{l}8 \text { locations } \\
196 \text { trees }\end{array}$ \\
\hline $\begin{array}{l}\text { Dry mixing during } \\
\text { installation }\end{array}$ & $\begin{array}{l}4 \text { locations } \\
141 \text { trees }\end{array}$ & $\begin{array}{l}1 \text { location } \\
22 \text { trees }\end{array}$ & - & - & - & $\begin{array}{l}5 \text { locations } \\
163 \text { trees }\end{array}$ \\
\hline Totals & $\begin{array}{l}17 \text { locations } \\
578 \text { trees }\end{array}$ & $\begin{array}{l}5 \text { locations } \\
37 \text { trees }\end{array}$ & $\begin{array}{l}7 \text { locations } \\
49 \text { trees }\end{array}$ & $\begin{array}{l}1 \text { location } \\
40 \text { trees }\end{array}$ & $\begin{array}{l}8 \text { locations } \\
114 \text { trees }\end{array}$ & $\begin{array}{l}38 \text { locations } \\
818 \text { trees }\end{array}$ \\
\hline
\end{tabular}


Table 3. Comparison of advantages and disadvantages of installation methods.

\begin{tabular}{ll}
\hline Mixing method & Advantages \\
\hline Premixing & $\begin{array}{l}\text { Can be done by machine } \\
\text { Risk of soil compaction in voids } \\
\text { Can require special mixing equipment }\end{array}$ \\
$\begin{array}{l}\text { Water mixing during } \\
\text { installation }\end{array}$ & $\begin{array}{l}\text { Contact between stones is ensured } \\
\text { Independent of weather } \\
\text { Prevents soil compaction }\end{array}$ \\
$\begin{array}{l}\text { Dry mixing during } \\
\text { installation }\end{array}$ & $\begin{array}{l}\text { Contact between stones is ensured } \\
\text { Prevents soil compaction }\end{array}$ \\
Sand mix & $\begin{array}{l}\text { Rational mixing with right equipment } \\
\text { Inexpensive ingredients } \\
\text { Easy to install }\end{array}$ \\
\hline
\end{tabular}

All examples presented in this article were established between 1991 and 1996. None of these trees have been measured for growth rates. Fast and accurate results were obtained by conducting growth experiments with 8 materials and 3 tree species beginning in spring 1994 . These results illustrate the growth capacities of the different materials (Kristoffersen 1998).

Acknowledgements. The author wishes to thank the municipalities involved in the planning and the construction of the cases studied. Thanks are also due to $\mathrm{Dr}$. Thomas B. Randrup for valuable discussions in connection with this paper.

\section{Literature Cited}

Bonsen, K.J.M. 1996. Architecture, growth dynamics and autoecology of the sycamore (Acer pseudoplatanus L.). Arboric. J. 3:339-354.

Couenberg, E.A.M. 1994. Amsterdam tree soil, pp 2433. In Watson, G.W., and D. Neely (Eds.). The Landscape Below Ground: Proceedings of an International Workshop on Tree Root Development in Urban Soils. International Society of Arboriculture, Champaign, IL.

Grabosky, J., and N. Bassuk. 1995. A new urban tree soil to safely increase rooting volumes under sidewalks. J. Arboric. 21(4):187-201.

Harris, Richard W. 1992 (2nd ed.). Arboriculture: Integrated Management of Landscape Trees, Shrubs, and Vines. Prentice Hall, Englewood Cliffs, NJ.

Harris, W.L. 1971. The soil compaction process, pp 9-44. In Barnes, K.K. (Ed.). Compaction of Agricultural Soils. The American Society of Agricultural Engineers, St. Joseph, MI.
Disadvantages

Separation during transportation and installation

Can require large volumes of water

Most suitable at large aggregate sizes

Dry weather required

Requires dry soil

Risk of soil compaction to a degree that impedes root growth The compaction level must be controlled

Poor load-bearing capacity

Kopinga, J. 1985. Site preparation practice in the Netherlands. Metria 5:72-84.

Kopinga, J. 1991. The effect of restricted volumes of soil on the growth and development of street trees. J. Arboric. 17(3):57-63.

Kopinga, J. 1992. Some Aspects of the Damage to Asphalt Road Pavings Caused by Tree Root, Including Some Preventive Control Methods. Proceedings from the 10th Osnabrücker Baumpflegetage, pp. 10.1-10.23.

Kristoffersen, P. 1998. Growing trees in road base materials. Arboric. J. In print.

Lichter, J.M., and P.A. Lindsey. 1994. Soil Compaction and Site Construction: Assessment and Case Studies, pp 126-130. In Watson, G.W., and D. Neely (Eds.). The Landscape Below Ground: Proceedings of an International Workshop on Tree Root Development in Urban Soils. International Society of Arboriculture, Champaign, IL.

Lindsey, P., and N. Bassuk. 1992. Redesigning the urban forest from the ground below: A new approach to specifying adequate soil volumes for street trees. J. Arboric. 16:25-39.

Patterson, J.C. 1977. Soil compaction-effects on urban vegetation. J. Arboric. 3(9):161-167.

Randrup, T.B. 1997. Soil compaction on construction sites. J. Arboric. 23(5):207-210.

Smith, K. 1995. Soil Aeration Systems: Do They Work?, pp 17-21. In Watson G.W., and D. Neely (Eds.). Trees and Building Sites: Proceedings of an International Workshop on Trees and Buildings. International Society of Arboriculture, Champaign, IL.

Teilmann, S., and P. Kristoffersen. 1996. Anlægsmetoder for bytræer i 11 kommuner. Videnblad nr. 4.6-19. Forskningscentret for Skov \& Landskab. In Danish. 
Urban, J. 1989. New techniques in urban tree plantings. J. Arboric. 15:281-284.

Vejdirektoratet. 1984. Vejregler for dimensionering af befæstelser. Katalog. 4 pp. In Danish.

\section{Palle Kristoffersen}

Research Landscape Architect

Danish Forest and Landscape Research Institute Department of Park and Landscape

Horsholm Kongevej 11

DK-2970 Horsholm

Denmark

Résumé. Au Danemark, les conditions pauvres de croissance pour les arbres en milieu urbain ont été perÿues comme un problème depuis les années ' 80 . Les dimensions restreintes des fosses de plantation sont principalement responsables de ce problème. Une recherche effectuée en 1996 a mis en lumière le fait que les fosses moyennes de plantation en milieu municipal sont passées de $0,1 \mathrm{~m} \geq$ à la fin des années ' 60 à $3,4 \mathrm{~m} \geq$ en 1996. Pour augmenter le volume de la fosse, plusieurs matériaux ont été introduits en mélange avec le sol afin de permettre aux racines de s'étendre sous le pavage. Trois méthodes sont possibles pour introduire le matériel sous la surface pavée. Au cours des cinq dernières années, plus de 800 arbres ont été plantés dans plus de 30 sites avec ces matériaux et ces méthodes d'insertion. Chacune de ces méthodes a ses avantages et ses inconvénients. Aucun problème sérieux imputable à la capacité de support des matériaux ou au soulèvement par le gel n'a été rapporté.

Zusammenfassung. In Dänemark wird seit den $80 \mathrm{ger}$ Jahren das Problem der armseligen Wachstumsbedignungen der Stadtbäume erkannt. 1996 fand eine Studie heraus, das die durchschnittliche Größe die kommunalen Baumscheiben vom $0,1 \mathrm{~m}^{3}$ in den späten 60 ger bis zu $3,4 \mathrm{~m}^{3}$ angestiegen ist. Um das Volumen der Pflanzgruben zu vergrößern, wurden verschiedene Materialien eingeführt, um im Mix mit dem Boden Wurzelwachstum zu ermöglichen. Es sind drei Methoden zur Einbringung von Materialien unter der Bepflasterung durchzusetzen. Während der letzten 5 Jahre wurden mehr als 800 Bäume an mehr als 40 Standorten gepflanzt, die diese Nachteile. Es wurden keine größen Schwierigkeiten wegen der Ladekapazität oder Frostverwerfungen gemeldet. 